\title{
Chronic leucine exposure results in reduced but reversible glucose-stimulated insulin secretion in INS-1 cells
}

\author{
XIUJUAN ZHANG $^{1 *}$, WENXIA HAN $^{1 *}$, XIUYUN JIANG ${ }^{1}$, MIN LI $^{1}$, LING GAO $^{2}$ and JIA JUN ZHAO ${ }^{1}$ \\ ${ }^{1}$ Department of Endocrinology; ${ }^{2}$ The Scientific Center, Shandong Provincial Hospital Affiliated to Shandong University, \\ Jinan, Shandong 250021, P.R. China
}

Received July 25, 2013; Accepted March 3, 2014

DOI: $10.3892 / \mathrm{mmr} .2014 .2122$

\begin{abstract}
Previous studies have demonstrated that sustained high leucine exposure decreases glucose-stimulated insulin secretion (GSIS). However, whether this effect is recoverable following the removal of leucine is unclear.Pancreatic/duodenal homeobox-1 (PDX-1) and its downstream target, glucose transporter 2 (GLUT2), are reported to be positively associated with insulin secretion. However, it also remains unclear whether the effect of leucine on GSIS is accompanied by alterations in PDX-1 and GLUT2. In the present study, insulin secretion, insulin content, PDX-1 and GLUT2 protein expression in INS-1 (rat insulinoma cell line) cells were assessed following a 24-h incubation in $40 \mathrm{mmol} / 1$ leucine. Half of the cells were incubated in leucine-free media for a further $24 \mathrm{~h}$ to observe the abovementioned effects. In contrast to the control, $40 \mathrm{mmol} / 1$ leucine for 24 or $48 \mathrm{~h}$ diminished GSIS at high glucose concentrations by $11 \%(\mathrm{P}=0.026)$ or $22 \%(\mathrm{P}=0.003)$, insulin content by $14 \%(\mathrm{P}=0.008)$ or $20 \%(\mathrm{P}=0.002)$, as well as decreasing PDX-1 and GLUT2 expression. When leucine was removed from the media for a further 24-h incubation, in comparison with those cells that were maintained in leucine treatment for 24 and $48 \mathrm{~h}$, the high GSIS increased by $13 \%$ $(\mathrm{P}=0.032)$ and $27 \%(\mathrm{P}=0.002)$, insulin content was augmented by $10 \%(\mathrm{P}=0.014)$ and $20 \%(\mathrm{P}=0.003)$, and the protein expression of PDX-1 and GLUT2 also increased. The present study demonstrates that sustained high concentrations of leucine induce a reversible impairment of GSIS and alter insulin content, which is mediated by PDX-1 and GLUT2, in INS-1 cells.
\end{abstract}

Correspondence to: Professor Jia Jun Zhao, Department of Endocrinology, Shandong Provincial Hospital Affiliated to Shandong University, 324 Jing 5 Road, Jinan, Shandong 250021, P.R. China

E-mail: jjzhao@medmail.com.cn

${ }^{*}$ Contributed equally

Key words: leucine, glucose-stimulated insulin secretion, pancreatic/duodenal homeobox-1, glucose transporter 2

\section{Introduction}

Type 2 diabetes mellitus (T2DM) is characterized by beta-cell dysfunction and inadequate insulin release in response to glucose $(1,2)$. In recent years, due to socioeconomic developments and the improvement of living standards, the incidence and prevalence of T2DM is increasing annually. It is becoming a major social issue, which threatens the lives and health of the public. Thus, for the effective prevention of T2DM, an in-depth discussion on the etiology and risk factors associated with T2DM is considered to be of significance.

Recent studies have elucidated the effects of glucose or free fatty acids (FFA) on insulin secretion and content $(3,4)$. Previous studies have reported that high glucose and FFA may cause impairment of pancreatic beta cells (5-8). In comparison with glucose or FFA, few studies have investigated the effect of amino acids on insulin secretion and content. Leucine, a branched chain amino acid, has been reported to be closely associated with insulin secretion and content (9-11). Previous studies have demonstrated that long-term leucine culture decreases glucose-stimulated insulin secretion (GSIS) in vitro (11). However, whether this detrimental effect is reversible, and the underlying mechanism of the effect, remain unclear.

Pancreatic/duodenal homeobox-1 (PDX-1) is important in pancreatic beta cell differentiation and insulin secretion (12-14). It transactivates the expression of insulin as well as other beta cell-specific genes, including glucose transporter 2 (GLUT2) (15-18). Previous studies reported that PDX-1 gene disruption resulted in aplasia $(12,19)$ and overexpression of PDX-1 restored beta cell function (20). Numerous studies reported that prolonged exposure to glucose or FFA induced a marked decrease in PDX-1 expression, which depressed the activity of GLUT2 and was associated with a decline in insulin secretion and content (21-23). However, it remains unclear whether the effects of leucine on insulin secretion and content are accompanied by alterations in PDX-1 and GLUT2.

The aim of the present study was to estimate the effects of sustained leucine exposure on insulin secretion, insulin content and the protein expression levels of PDX-1, as well as its downstream target, GLUT2 in INS-1 cells. Furthermore, whether these effects are reversible or not, following the removal of high concentrations of leucine, was investigated. 


\section{Materials and methods}

Cell culture and treatment. INS-1 (rat insulinoma cell line) cells were grown in a monolayer culture of RPMI-1640 media containing $11.1 \mathrm{mmol} / 1$ glucose supplemented with $10 \mathrm{mmol} / \mathrm{l}$ 4-(2-hydroxyethyl)-1-piperazineethanesulfonic acid, 10\% fetal bovine serum, $1 \mathrm{mmol} / 1$ sodium pyruvate, $2 \mathrm{mmol} / \mathrm{l}$ L-glutamine, $50 \mu \mathrm{mol} / 1 \beta$-mercaptoethanol, $100 \mathrm{IU} / \mathrm{ml}$ penicillin and $100 \mu \mathrm{g} / \mathrm{ml}$ streptomycin at $37^{\circ} \mathrm{C}$ in a humidified atmosphere with $5 \% \mathrm{CO}_{2}(4)$. The cells (passages <40) were employed for the experiment at $80-90 \%$ confluence. The INS-1 cells were treated in the presence or absence of elevated concentrations of leucine $(10,20$ or $40 \mathrm{mmol} / \mathrm{l})$ for $24 \mathrm{~h}$.

Insulin secretion and insulin content assays. INS-1 cells $\left(1.5 \times 10^{5}\right.$ cells/well) were firstly incubated overnight in 24-well plates (Corning Incorporated, Corning, NY, USA) with standard media (no leucine) and allowed to attach and treated in the presence or absence of $40 \mathrm{mmol} / 1$ leucine for $24 \mathrm{~h}$. Secondly, half of the plates that were cultured in the presence or absence of leucine were used to determine insulin secretion. The cells in the remaining plates were incubated further and the cells that received the leucine pretreatment were divided into two groups: One was maintained in a media containing leucine and the other was cultured in a leucine-free media. Following a further 24-h culture, insulin secretion was determined by an insulin radioimmunoassay (RIA) kit (Beijing Atom HighTech Co. Ltd., Beijing, China). For insulin secretion, the cells were gently washed twice with prewarmed phosphate-buffered saline (PBS) and incubated in prewarmed Krebs-Ringer bicarbonate buffer (KRB) containing $3 \mathrm{mmol} / \mathrm{l}$ glucose for $20 \mathrm{~min}$ at $37^{\circ} \mathrm{C}$. The buffer was removed and half of the plates were cultured in $\mathrm{KRB}$ containing $3 \mathrm{mmol} / \mathrm{l}$ glucose and the remaining half were incubated in KRB containing $27.8 \mathrm{mmol} / \mathrm{l}$ glucose. Following an additional $20 \mathrm{~min}$ incubation at $37^{\circ} \mathrm{C}$, aliquots of the medium were collected from each well and stored at $-20^{\circ} \mathrm{C}$ for a subsequent insulin secretion test with the RIA kit. To measure the protein content, the cells were washed twice with KRB and RIPA lysis buffer was added (Shenneng Bo Cai Co. Ltd, Shanghai, China). The intracellular protein concentration was determined using a bicinchoninic acid (BCA) protein assay kit (Bio-Rad, Hercules, CA, USA). Insulin secretion was normalized based on the corresponding protein content.

In order to test the insulin content, $500 \mu 1 \mathrm{acid} / \mathrm{ethanol}$ ( $75 \% \mathrm{v} / \mathrm{v}$ ethanol, $1.5 \% \mathrm{v} / \mathrm{v}$ concentrated $\mathrm{HCl}$ ) was added to the plates. The acid ethanol aliquots were used to measure insulin content with the RIA kit. The total protein content was determined as described above and the insulin content was normalized based on the respective cellular protein content.

Protein analysis by western blotting. The cultured INS-1 cells were washed twice with ice-cold PBS and the cells were lysed using RIPA lysis buffer supplemented with $1 \mathrm{mmol} / 1$ phenylmethylsulfonyl fluoride on ice for $10 \mathrm{~min}$. The lysate solution was centrifuged (Eppendorf, Hamburg, Germany) at 10,000 x g for $10 \mathrm{~min}$ at $4^{\circ} \mathrm{C}$. The protein concentration was determined by a BCA assay. The protein extracts (60 $\mu \mathrm{g}$ total protein for GLUT2 and $40 \mu \mathrm{g}$ protein for PDX-1) were separated by $10 \%$ and $12 \%$ SDS-PAGE for GLUT2 and PDX-1, respectively. The proteins in the gel were subsequently transferred onto nitrocellulose membranes (Millipore, Billerica, MA, USA). The membranes were washed once with $1 \mathrm{X}$ TBST $(10 \mathrm{mmol} / \mathrm{l}$ Tris, $150 \mathrm{mmol} / \mathrm{l}$ $\mathrm{NaCl}$ and $0.1 \%$ Tween 20) prior to blocking with $5 \%$ non-fat milk at room temperature for $1 \mathrm{~h}$. The membranes were gently agitated overnight (Biocotek Scientific Instrument Co., Ningbo, China) at $4^{\circ} \mathrm{C}$ with 1:10,000 PDX-1 antibody (Chemicon, NY, USA) or 1:200 GLUT2 antibody (Santa Cruz Biotechnology, Inc., Santa Cruz, CA, USA). The membranes were washed three times (3x10 min) with 1X TBST and incubated with the corresponding second antibodies at room temperature for $1 \mathrm{~h}$. Finally, the proteins were visualized by enhanced chemiluminescence (Amersham Biosciences UK Limited, Amersham, England). The membranes were reblocked and incubated with mouse anti- $\beta$-actin monoclonal antibody (Abcam, Cambridge, UK).

Immunofluorescence. The location and expression of PDX-1, insulin and GLUT2 were examined by immunofluorescence. INS-1 cells were plated on polyornithine-coated glass coverslips for 24 h. Rabbit anti-PDX-1 (Santa Cruz Biotechnology, Inc.), mouse anti-insulin (DakoCytomation, Glostrup, Denmark) and rabbit anti-GLUT2 antibodies (Santa Cruz Biotechnology, Inc.) were used for the experiment. The resultant immunofluorescence was viewed under a fluorescent microscope (Leica DMIRE2; Leica Microsystems GmbH, Wetzlar, Germany).

Statistical analysis. All values are provided as the mean \pm standard deviation. Statistical analysis was calculated using a one-way analysis of variance and $\mathrm{P}<0.05$ was considered to indicate a statistically significant difference.

\section{Results}

Expression of GLUT2, PDX-1 and insulin in INS-1 cells. GLUT2, PDX-1 and insulin were all expressed in the INS-1 cells. GLUT2 was predominantly expressed in the cell membrane (Fig. 1A), while PDX-1 and insulin were predominantly expressed in the cytoplasm (Fig. 1B and C).

Effects of increasing concentrations of leucine on insulin secretion and content. In order to investigate the effects of leucine on insulin secretion and content, INS-1 cells were cultured in a medium in the presence or absence of increasing concentrations of leucine for $24 \mathrm{~h}$. The cells were used to determine insulin secretion and intracellular insulin content at low and high levels of glucose stimulation. The results demonstrated that 24-h incubation with increasing concentrations of leucine led to a decrease of high GSIS and insulin content; the effect was significant at $40 \mathrm{mmol} / 1$ leucine. In contrast to the control, a $40-\mathrm{mmol} / \mathrm{l}$ leucine treatment decreased high GSIS by $11 \%(\mathrm{P}=0.026$; Fig. $2 \mathrm{~A})$ and insulin content by $14 \%(\mathrm{P}=0.008$; Fig. 2B), however, it did not affect the insulin secretion level at low glucose stimulation $(\mathrm{P}=0.01$; Fig. $2 \mathrm{~A})$. In contrast to the control, neither 10 nor $20 \mathrm{mmol} / \mathrm{l}$ leucine produced a significant decrease in insulin secretion $(\mathrm{P}=0.645$ and $\mathrm{P}=0.250$; Fig. 2A) and insulin content ( $\mathrm{P}=0.870$ and $\mathrm{P}=0.279$; Fig. $2 \mathrm{~B})$.

Effects of increasing concentrations of leucine on PDX-1 and GLUT2 expression. The cells were treated as previously described. The PDX-1 protein band became weaker with increasing concentration and the effect was significant with 


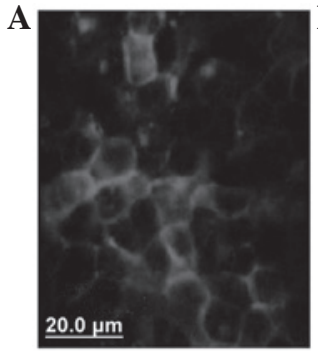

GLUT2

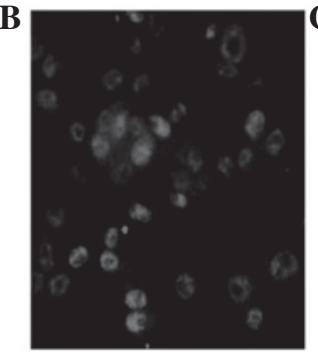

PDX-1

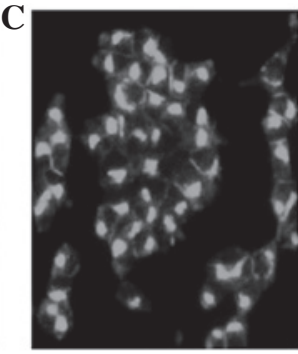

Insulin

Figure 1. Expression of (A) GLUT2, (B) PDX-1 and (C) insulin in rat insulinoma cell line, INS-1, cells. GLUT2 was predominantly expressed in the cell membrane, while PDX-1 and insulin were predominantly expressed in the cytoplasm. GLUT2, glucose transporter 2; PDX-1, pancreatic/duodenal homeobox-1.

A

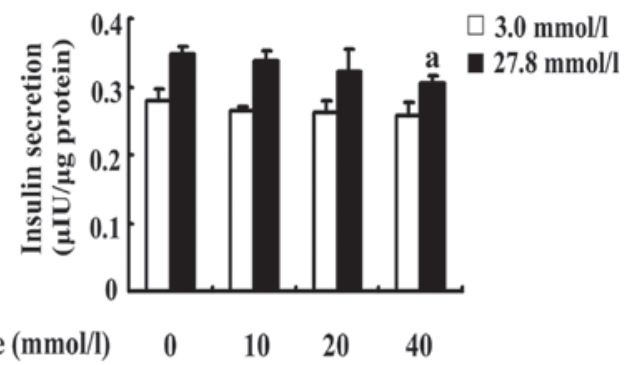

B

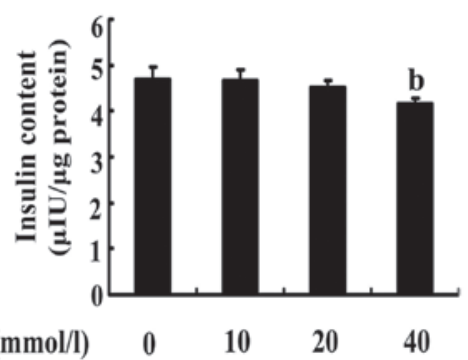

Figure 2. Effects of increasing concentrations of leucine on insulin secretion and content. (A) Insulin secretion at $3 \mathrm{mmol} / \mathrm{l}$ glucose and $27.8 \mathrm{mmol} / \mathrm{lglu}-$ cose. (B) Intracellular insulin content was determined by radioimmunoassay. Each value represents the mean \pm standard deviation. ${ }^{\mathrm{a}} \mathrm{P}=0.026$ and ${ }^{\mathrm{b}} \mathrm{P}=0.008$ vs. the control group; $\mathrm{n}=4$.

a 40-mmol/1 leucine treatment ( $\mathrm{P}=0.013$; Fig. 3A). Similarly, GLUT2 demonstrated the same trend as PDX-1 and the weakest band was observed in cells that were treated with $40 \mathrm{mmol} / \mathrm{l}$ leucine ( $\mathrm{P}=0.011$; Fig. 3B).

Effects on insulin secretion and content of a 24-h recovery in a standard medium. To investigate whether GSIS and insulin content is recoverable following the removal of a high concentration of leucine, INS-1 cells were firstly treated in the absence or presence of $40 \mathrm{mmol} / \mathrm{l}$ leucine for $24 \mathrm{~h}$ and the cells that had received a leucine pretreatment were divided into two groups: One was maintained in a medium containing leucine and the other was cultured in a standard medium for a further $24 \mathrm{~h}$. The results indicated that, in contrast to the corresponding control, a 40 -mmol/l leucine treatment for $24 \mathrm{~h}$ decreased GSIS at high glucose concentrations by $11 \%$ ( $\mathrm{P}=0.026$; Fig. $4 \mathrm{~A})$ and insulin content by $14 \%$ ( $\mathrm{P}=0.008$; Fig. 4B). In addition, a $40-\mathrm{mmol} / \mathrm{l}$ leucine treatment for $48 \mathrm{~h}$ decreased GSIS at high glucose concentrations by $22 \%(\mathrm{P}=0.003$; Fig. $4 \mathrm{~A})$ and insulin content
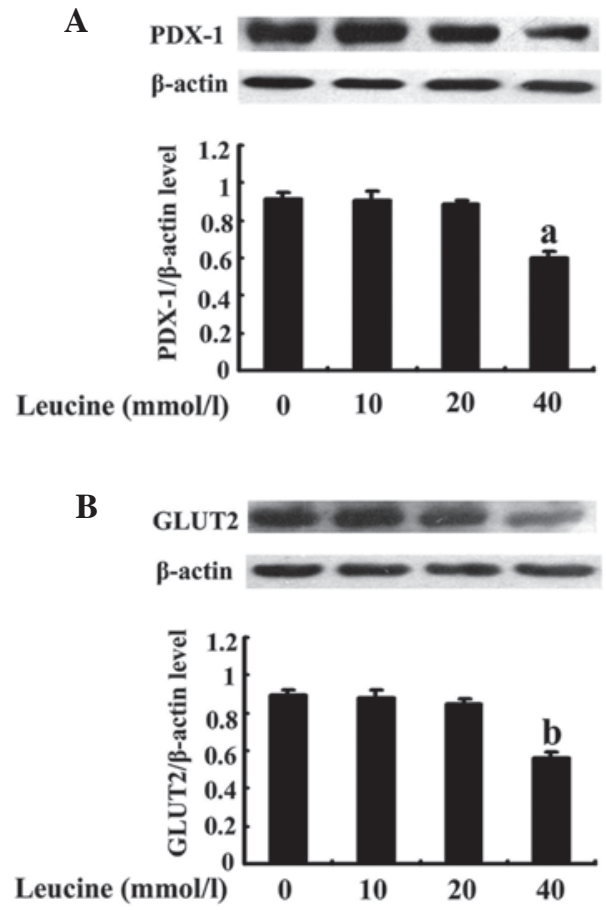

Figure 3. Effects of increasing concentrations of leucine on PDX-1 and GLUT2 expression. Western blotting was performed to detect the protein expression of (A) PDX-1 and (B) GLUT2. ${ }^{\mathrm{a}} \mathrm{P}=0.013$ and ${ }^{\mathrm{b}} \mathrm{P}=0.011$ vs. the control group; $\mathrm{n}=3$. PDX-1, pancreatic/duodenal homeobox-1; GLUT2, glucose transporter 2 .

by $20 \%$ ( $\mathrm{P}=0.002$; Fig. 4B). When leucine was removed from the media and the cells were incubated for an additional $24 \mathrm{~h}$, the high GSIS was increased by $13 \%(\mathrm{P}=0.032$; Fig. $4 \mathrm{~A})$ and $27 \%(\mathrm{P}=0.002$; Fig. $4 \mathrm{~A})$ and insulin content was augmented by $10 \%(\mathrm{P}=0.014$; Fig. 4B) and 20\% ( $\mathrm{P}=0.003$; Fig. 4B) compared with those in the cells that were maintained in the leucine treatment for 24 or $48 \mathrm{~h}$, respectively.

Effects on PDX-1 and GLUT2 expression of a 24 h recovery in standard medium. The results demonstrated that in contrast to the control, a 24-h leucine treatment decreased PDX-1 (Fig. 5A) and GLUT2 (Fig. 5B) protein expression and the effects were statistically significant in cells that were treated with leucine for $48 \mathrm{~h}$. The reduced PDX-1 and GLUT2 protein expression, which was induced by a 24-h leucine treatment almost recovered to normal in cells that were initially treated with leucine for $24 \mathrm{~h}$ and subsequently allowed a $24-\mathrm{h}$ recovery in standard medium ( $\mathrm{P}=0.013$, Fig. 5A; $\mathrm{P}=0.015$, Fig. 5B). In comparison 

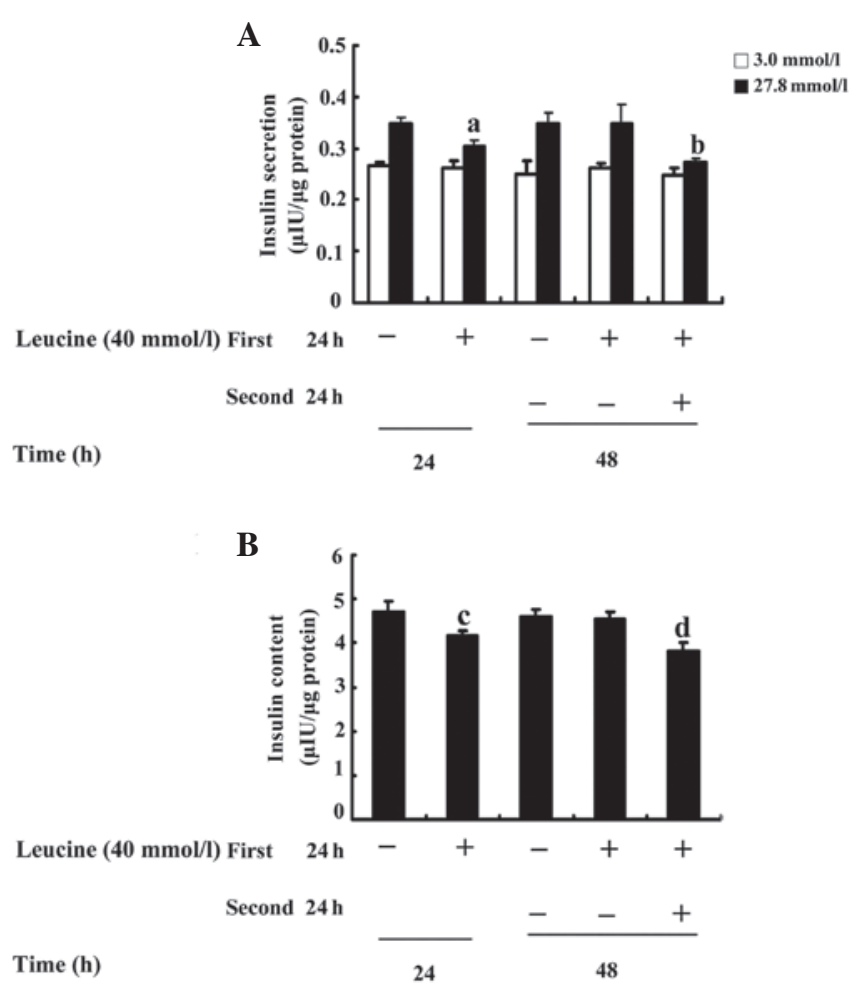

Figure 4. Effect on insulin secretion and content of $24 \mathrm{~h}$ recovery in standard medium. (A) Insulin secretion at $3 \mathrm{mmol} / 1$ glucose and $27.8 \mathrm{mmol} / \mathrm{l}$ glucose. (B) Intracellular insulin content. Each value represents the mean \pm standard. ${ }^{\mathrm{a}} \mathrm{P}=0.026,{ }^{\mathrm{b}} \mathrm{P}=0.003,{ }^{\mathrm{C}} \mathrm{P}=0.008$ and ${ }^{\mathrm{d}} \mathrm{P}=0.002$ vs. the corresponding control group; ${ }^{\mathrm{a}} \mathrm{P}=0.032$ and ${ }^{\mathrm{b}} \mathrm{P}=0.002$ vs. the $24 \mathrm{~h}$ recovery group; ${ }^{\mathrm{C}} \mathrm{P}=0.014$ and ${ }^{\mathrm{d}} \mathrm{P}=0.003$, vs. $24 \mathrm{~h}$ recovery group; $\mathrm{n}=4$.

with cells that were maintained in the leucine treatment for $48 \mathrm{~h}$, the PDX-1 and GLUT2 protein bands in the cells with a 24-h recovery in standard medium were significantly strengthened ( $\mathrm{P}=0.005$, Fig. 5A; $\mathrm{P}=0.006$, Fig. 5B).

\section{Discussion}

In the present study, it was demonstrated that a 24-h incubation of elevated-concentration leucine treatment resulted in a dose-dependent decrease of GSIS and intracellular insulin content in INS-1 cells, accompanied by an impaired protein expression of PDX-1 and its downstream target, GLUT2. It was identified that in the INS-1 cells, which were able to recover for a further $24 \mathrm{~h}$ in a standard medium following the 24-h high leucine incubation, the impaired protein expression of PDX-1 and GLUT2 was completely reversed.

With regard to the effects of leucine on GSIS, Anello et al (9) reported that leucine decreased GSIS in a dose-dependent manner and $20 \mathrm{mmol} / \mathrm{l}$ leucine significantly reduced GSIS in islets. The present study demonstrated that a $24-\mathrm{h}$ incubation with increasing concentrations of leucine decreased high GSIS in a dose-dependent manner and the effect was significant at $40 \mathrm{mmol} / \mathrm{l}$ leucine. Furthermore, elevated concentrations of leucine decreased the insulin content in a dose-dependent manner, which further verified the results. The results were partially in agreement with the study by Anello et al (9) and the disparity may be due to different experimental conditions, including the type of cells. Furthermore, additional studies were found that used $40 \mathrm{mmol} / \mathrm{l}$ leucine (24-26). In our previous study,

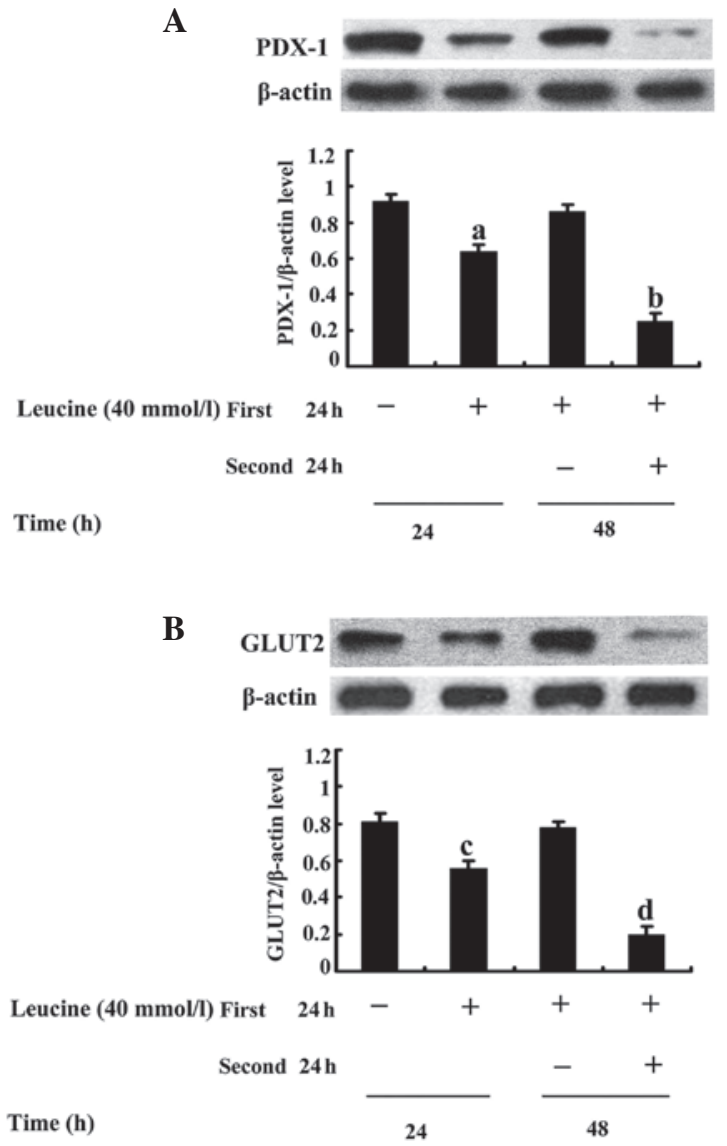

Figure 5. Effect on PDX-1 and GLUT2 expression of $24 \mathrm{~h}$ recovery in standard medium. Western blotting was performed to detect the protein expression of (A) PDX-1 and (B) GLUT2. ${ }^{\mathrm{P}} \mathrm{P}=0.013,{ }^{\mathrm{b}} \mathrm{P}=0.005,{ }^{\mathrm{C}} \mathrm{P}=0.015$ and ${ }^{\mathrm{d}} \mathrm{P}=0.006$ vs. the $24 \mathrm{~h}$ recovery group; $\mathrm{n}=3$. PDX-1, pancreatic/duodenal homeobox-1; GLUT2, glucose transporter 2.

it was identified via CCK- 8 assay that $40 \mathrm{mM}$ leucine did not significantly inhibit cell viability, compared with corresponding controls, in INS-1 cells (27). Although data resulting from high leucine concentrations have limited physiological significance, the high concentration may alter pancreatic beta cell function. Furthermore, the data may provide insight into the signaling pathway of gene regulation in beta cells, including PDX-1, GCK and GLUT2, which are important in beta cell function and in the development of diabetes.

The role of PDX-1 in pancreatic beta-cell insulin secretion is due to its effect on transactivating the expression of insulin and other beta cell-specific genes, including GCK and GLUT2. That is to say, either PDX-1 or GLUT2 is closely correlated with insulin and may, therefore, be an index of insulin measurement. Numerous studies in vitro and in vivo indicated that prolonged exposure to glucose or FFA may induce a marked decrease in PDX-1 expression $(21,22,23)$. However, to the best of our knowledge, a study that focuses on the effect of leucine on PDX-1 has not yet been reported. In the present study, it was demonstrated that prolonged exposure to leucine downregulated the protein expression of PDX-1 and its downstream target, GLUT2, in INS-1 cells indicating a possible role of leucine in PDX-1 protein expression. These data indicate that sustained exposure to leucine decreased high GSIS and insulin content, which was accompanied by the impairment of PDX-1 
and GLUT2 protein expression. Furthermore, variations in PDX-1 and GLUT2 protein expression were closely correlated with the leucine concentration. The concordant changes of PDX-1 and insulin content observed in the present study were in agreement with the results from Sun et al (3).

An additional finding of the present study was that all of the detrimental effects associated with decreased GSIS, insulin content, PDX-1 and GLUT2 protein expression were completely recovered to normal once INS-1 cells were allowed a 24-h recovery in standard medium following the 24-h exposure to leucine. The detrimental effects that occurred in the cells, which were treated with leucine continuously for $48 \mathrm{~h}$, were more serious compared with those observed in cells that had undergone a 24-h leucine incubation. All results demonstrated that $40 \mathrm{mmol} / \mathrm{l}$ leucine impaired GSIS and insulin content, which accompanied PDX-1 and GLUT2 protein alterations. It appeared that the impairment of GSIS, PDX-1 and GLUT2 protein expression that was induced by the sustained leucine exposure was reversible. At present, the environment is considered to be an independent factor for the pathogenesis of diabetes. From the present study, it was hypothesized that eliminating harmful environmental factors may enable the recovery of the impaired insulin secretion levels. However, it remains unclear whether the effect of sustained leucine exposure on PDX-1 is direct or indirect. Furthermore, whether leucine requires metabolization for its effect requires further investigation, which could be conducted via a comparison between leucine and nonmetabolized leucine analog 2-amino-2-norbornane-carboxylic acid.

In conclusion, the present study demonstrates that sustained high concentrations of leucine exposure for $24 \mathrm{~h}$ induces the reversible impairment of high GSIS, insulin content, PDX-1 and GLUT2 expression in INS-1 cells. At present, environmental factors are deemed independent. The present study demonstrates a novel approach to the prevention and treatment of diabetes by reducing high concentrations of amino acid and mediating the PDX-1 and GLUT2 signaling pathway.

\section{Acknowledgements}

The authors would like to thank Professor X Han for providing the INS-1 cells and the teachers at the Science Center of Shandong Provincial Hospital (Jinan, China) for their technical assistance. The present study was funded by grants from the National Natural Science Foundation of China (grant no. 81000325), the Excellent Young Scientist Award Foundation of Shandong Province (grant no. BS2010YY050) and the Natural Science Foundation of Shandong Province (grant no. ZR2009CM101).

\section{References}

1. DeFronzo RA, Bonadonna RC and Ferrannini E: Pathogenesis of NIDDM. A balanced overview. Diabetes Care 15: 318-368, 1992.

2. Porte D Jr and Kahn SE: beta-cell dysfunction and failure in type 2 diabetes: potential mechanisms. Diabetes 50 (Suppl 1): S160-S163, 2001.

3. Sun Y, Zhang L, Gu HF, et al: Peroxisome proliferator-activated receptor-alpha regulates the expression of pancreatic/duodenal homeobox-1 in rat insulinoma (INS-1) cells and ameliorates glucose-induced insulin secretion impaired by palmitate Endocrinology 149: 662-671, 2008.

4. Van de Casteele M, Kefas BA, Cai Y, et al: Prolonged culture in low glucose induces apoptosis of rat pancreatic beta-cells through induction of c-myc. Biochem Biophys Res Commun 312: 937-944, 2003
5. Unger RH and Zhou YT: Lipotoxicity of beta-cells in obesity and in other causes of fatty acid spillover. Diabetes 50 (Suppl 1): S118-S121, 2001.

6. Ling Z and Pipeleers DG: Prolonged exposure of human beta cells to elevated glucose levels results in sustained cellular activation leading to a loss of glucose regulation. J Clin Invest 98: 2805-2812, 1996.

7. Briaud I, Harmon JS, Kelpe CL, Segu VB and Poitout V: Lipotoxicity of the pancreatic beta-cell is associated with glucose-dependent esterification of fatty acids into neutral lipids. Diabetes 50: 315-321, 2001.

8. Robertson RP, Harmon J, Tran PO and Poitout V: Beta-cell glucose toxicity, lipotoxicity, and chronic oxidative stress in type 2 diabetes. Diabetes 53 (Suppl 1): S119-S124, 2004.

9. Anello M, Ucciardello V, Piro S, et al: Chronic exposure to high leucine impairs glucose-induced insulin release by lowering the ATP-to-ADP ratio. Am J Physiol Endocrinol Metab 281: E1082-E1087, 2001.

10. Yang J, Wong RK, Park M, et al: Leucine regulation of glucokinase and ATP synthase sensitizes glucose-induced insulin secretion in pancreatic beta-cells. Diabetes 55: 193-201, 2006.

11. Yang J, Wong RK, Wang X, et al: Leucine culture reveals that ATP synthase functions as a fuel sensor in pancreatic beta-cells. J Biol Chem 279: 53915-53923, 2004.

12. Kaneto H, Miyatsuka T, Fujitani Y, et al: Role of PDX-1 and MafA as a potential therapeutic target for diabetes. Diabetes Res Clin Pract 77 (Suppl 1): S127-S137, 2007.

13. Fernandes A, King LC, Guz Y, Stein R, Wright CV and Teitelman G: Differentiation of new insulin-producing cells is induced by injury in adult pancreatic islets. Endocrinology 138: 1750-1762, 1997.

14. Offield MF, Jetton TL, Labosky PA, et al: PDX-1 is required for pancreatic outgrowth and differentiation of the rostral duodenum. Development 122: 983-995, 1996.

15. Waeber G, Thompson N, Nicod P and Bonny C: Transcriptional activation of the GLUT2 gene by the IPF-1/STF-1/IDX-1 homeobox factor. Mol Endocrinol 10: 1327-1334, 1996.

16. Marshak S, Totary H, Cerasi E and Melloul D: Purification of the beta-cell glucose-sensitive factor that transactivates the insulin gene differentially in normal and transformed islet cells. Proc Natl Acad Sci USA 93: 15057-15062, 1996.

17. Iype T, Francis J, Garmey JC, et al: Mechanism of insulin gene regulation by the pancreatic transcription factor Pdx-1: application of pre-mRNA analysis and chromatin immunoprecipitation to assess formation of functional transcriptional complexes. J Biol Chem 280: 16798-16807, 2005.

18. Melloul D, Marshak S and Cerasi E: Regulation of insulin gene transcription. Diabetologia 45: 309-326, 2002.

19. Jonsson J, Carlsson L, Edlund $\mathrm{T}$ and Edlund $\mathrm{H}$ : Insulin-promoter-factor 1 is required for pancreas development in mice. Nature 371: 606-609, 1994.

20. Kushner JA, Ye J, Schubert M, et al: Pdx1 restores beta cell function in Irs2 knockout mice. J Clin Invest 109: 1193-1201, 2002.

21. Gremlich S, Bonny C, Waeber G and Thorens B: Fatty acids decrease IDX-1 expression in rat pancreatic islets and reduce GLUT2, glucokinase, insulin, and somatostatin levels. J Biol Chem 272: 30261-30269, 1997.

22. Leahy JL, Cooper HE, Deal DA and Weir GC: Chronic hyperglycemia is associated with impaired glucose influence on insulin secretion. A study in normal rats using chronic in vivo glucose infusions. J Clin Invest 77: 908-915, 1986.

23. Xiao CQ, Deng HM and Huang Y: Effects of supraphysiologic concentration glucose on pancreatic duodenal homeobox-1 expression and insulin secretion in rats. Chin Med J (Engl) 120: 1020-1023, 2007

24. Lennernäs H, Nilsson D, Aquilonius SM, Ahrenstedt O, Knutson L and Paalzow LK: The effect of L-leucine on the absorption of levodopa, studied by regional jejunal perfusion in man. Br J Clin Pharmacol 35: 243-250, 1993.

25. Ganapathy V and Radhakrishnan AN: Interaction of amino acids with glycl-L-leucine hydrolysis and transport in monkey small intestine. Clin Sci (Lond) 57: 521-527, 1979.

26. Rideau N and Simon J: L-leucine or its keto acid potentiate but do not initiate insulin release in chicken. Am J Physiol 257: E15-E19, 1989.

27. Zhang X, Sun N, Wang L, et al: AMP-activated protein kinase and pancreatic/duodenal homeobox-1 involved in insulin secretion under high leucine exposure in rat insulinoma beta-cells. J Cell Mol Med 13: 758-770, 2009. 